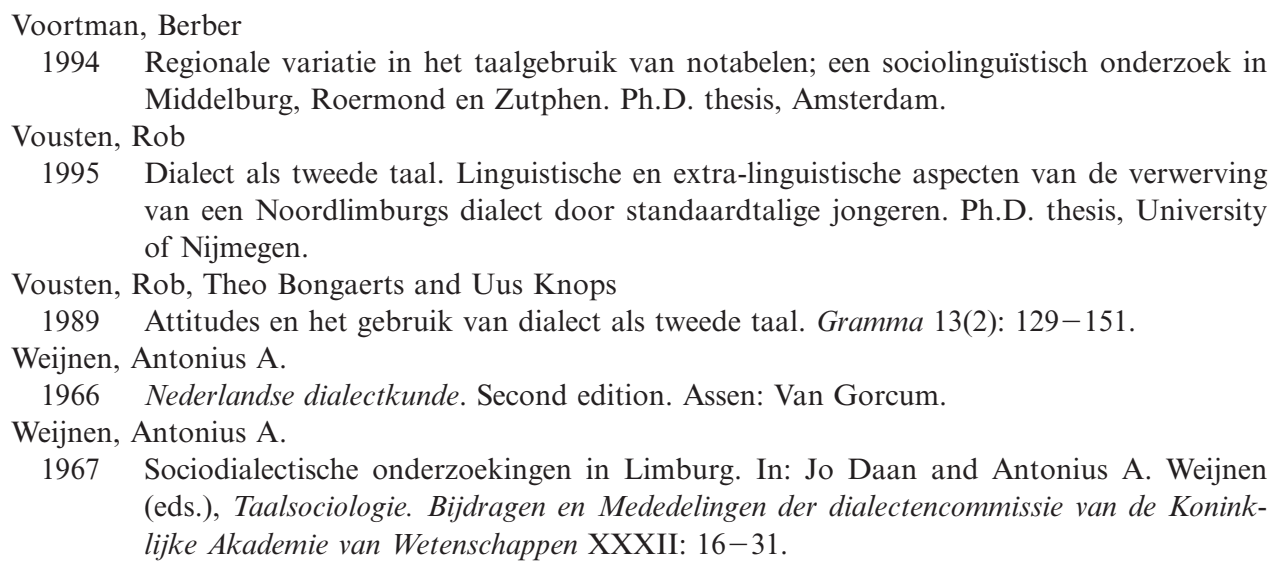

\title{
21. Holland and Utrecht: Phonology and phonetics
}

\author{
1. Introduction \\ 2. Phenomena \\ 3. Desiderata \\ 4. Atlases \\ 5. References
}

\section{Introduction}

In many languages of the world the name for the Netherlands is something similar to Holland. In Dutch, however, Holland usually refers only to a specific part of the country, viz. the two provinces North and South Holland. These contain the three largest cities, Amsterdam, Rotterdam and The Hague, and have formed the national cultural and economic centre for many centuries. Informal observation suggests that the name $\mathrm{Hol}$ land refers to all of the Netherlands outside the own region in the parlance of some dialect speakers outside of Holland; for instance, for Limburg speakers 'Holland' might refer to all of the Netherlands except for Limburg.

This explains the pars pro toto of the toponym, but also the special status of the dialects spoken in this region. For the outside observer, North Holland (which includes Amsterdam) and South Holland (which includes Rotterdam and The Hague) as well as the neighbouring very small province of Utrecht (whose capital city bears the same name) are strikingly underrepresented in the literature on Dutch dialectology. For example, the network of informants assigned to these provinces in the recent FAND, MAND and SAND dialect atlases is less finely grained than that for other parts of the Nether- 
lands, in spite of the fact that it is the most densely populated area. People familiar with the cultural and political situation in the Netherlands know the reason for this apparent paradox: Holland and Utrecht, which have been the socio-economic powerhouses for a long time, have influenced the formation of the standard language for a considerable time span, and are therefore deemed hardly to speak dialect. Another, related, reason may be that the urban dialects in particular have changed their function into sociolects, spoken by the working classes exclusively, or at least associated with these in the minds of most speakers.

It is difficult to find grammatical descriptions of these dialects, and since purely phonetic work specifically on these dialects is even more difficult to find, here we will concentrate mostly on the phonology. The phonological literature is also scarce, and usually consists of small sections in larger descriptions of the dialect for a broader audience.

There are two ways to divide the dialects in this area. According to traditional dialectology (e.g. Jo Daan's 1969 classification), there are two main groups: on the one hand, there are the 'Holland' dialects, which can be further subdivided into the South Holland varieties (spoken in the province of South Holland), the Westhoek varieties (spoken in North Brabant), the varieties spoken in Waterland and Volendam, Zaanstreek, Kennemerland, West-Friesland (all spoken in North Holland) and the mixed Hollandic/Frisian systems known as Bildts, Midslands, Stadsfries and Amelands (spoken in the province of Frisia, mostly on the Frisian islands - cf. Bloemhoff, De Haan and Versloot, Ch. 38 in this volume). On the other hand, there is the group of 'northern-central' dialects, including Utrecht and the eastern part of South Holland and the Gooi region of North Holland.

A distinction which may be even more relevant today is the one between urban dialects and rural dialects:

(a) Urban dialects which have received attention in the literature are those spoken in Amsterdam (Daan 1948, Schatz 1987, Brouwer 1989, Berns 2002), Rotterdam (Van Oostendorp 2002), The Hague (Elias 1977, 2002), Utrecht (Van Veen 1964, Martens van Vliet 2000). Of the smaller cities, some attention has gone to Leiden (Wortel 2002, Heestermans 2007). Most of these publications are directed towards a general audience. A special position is taken by Haarlem, which, according to an urban myth, does not have its own dialect. Winkler (1874) claimed that nineteenth century Amsterdam still had many different dialects, but already pointed out that these were mostly quickly disappearing. The later sources on Amsterdam just mentioned no longer recognize any dialect distinction.

(b) Three of the more rural areas have received specific attention: (i) West-Friesland (for which Pannekeet 1991 gives an impressive overview), (ii) the North Sea coast dialects of Katwijk (Overdiep 1940, De Vink 2004), Zandvoort (Van den Berg 1959), etc.) and (iii) the Waterland dialects, immediately north and northeast of Amsterdam (Van Ginneken 1954). Texel can be included into this group as well; the other Holland island (Vlieland) lost its dialect in the nineteenth century. One of the very few locations which cannot be grouped in either (i), (ii) or (iii) but has received serious treatment in the form of a monograph is the traditional dialect of Zoetermeer (Goeman 1984).

It is usually assumed that the phonology of the Holland and Utrecht dialects is not too different from that of SD. The segment inventory seems by and large the same (we will discuss potential differences in the vowel and consonant inventories in sections 2.1. and 
2.2., respectively), and it is difficult to mark anything as specific for the Holland and Utrecht dialects as opposed to either other dialects or the standard language. Most of the features discussed in this chapter can be found in other regions as well, although the specific cocktail of features is obviously unique to Holland and Utrecht. I have tried to concentrate on features which seem to have a clear 'centre' in the area under discussion.

It goes without saying that even within these larger regions there is considerable variation, in particular on the phonological and phonetic levels. Some of this has also received at least some attention in the literature and we will note this below. In this overview article, we will concentrate mostly on this, previously published, work in section 2. Section 3. will be devoted to some desiderata for future study of the Holland dialects.

I have decided to concentrate on synchronic rather than diachronic phonology here. This means that the discussion will not concentrate on historical processes of rounding or unrounding, raising and lowering which affect all words without any exceptions, but in particular on such aspects that have led to alternations in the synchronic phonologies. I will make an exception for some diachronic changes which have led also to discussion in the synchronic phonology literature, or where these have led to interesting patterns from a synchronic perspective. Furthermore, I concentrate on phenomena which more or less involve the whole area, except where noted explicitly. Given the paucity of dialect and dialect study in this region, it is next to impossible to distinguish large isoglosses within the area in question.

\section{Phenomena}

We will discuss the most relevant older and recent work which deals with the phonology of the dialects of both groups. I will first (2.1.) discuss certain phenomena related to vowels, then (2.2.) phenomena related to consonants and finally (2.3.) I will devote a few words to what little is known about specific Hollandic phenomena at the suprasegmental level.

\subsection{Vowels}

\subsubsection{The alternation between [ja] and [i]}

One of the most typical phonological phenomena found in this area is the alternation between the consonant-vowel sequence [jo] and the single vowel [i]. The first formal treatment of this phenomenon was given by B. van den Berg in an article in the general linguistics journal De Nieuwe Taalgids in 1973. Van den Berg discusses the alternation within the diminutive suffix in "the common language of families in the Randstad" (1973: 133; the Randstad is a conurbation in the Netherlands consisting of the four largest Dutch cities (Amsterdam, Rotterdam, The Hague and Utrecht), and the surrounding areas

In Van den Berg's view, the diminutive suffix has two variants (I will follow his transcriptions; as will become clear below, Van den Berg considers the vowel in the diminutive to be front rounded and not schwa; although this is no longer a majority view, I will adopt it here, as it does not seem very important): 
(a) tje [tjü] (where [ü] is a mid central rounded vowel) after a vowel, a diphthong or the sonorants $j, w, r$ and the nasals (see (1a))

(b) je [jü] after a basic morpheme ending in [t] (either derived from /d/ by final devoicing or underlying) (see (1b))

(c) ie [i] after the voiceless consonants $\mathrm{p}, \mathrm{f}, \mathrm{s}, \mathrm{k}, \mathrm{x}$ (see (1c))

The following examples may clarify this distribution. I give the SD form of the stem in parentheses:

(1) a. paatje (pa) 'father', zeetje (zee) 'sea', eitje (ei) 'egg', kooitje (kooi) 'cage', paartje (paar) 'pair', kraaltje (kraal) 'bead', mannetje (man) 'man', vlaggetje (flag) 'flag'. The last two examples involve schwa insertion, as Van den Berg points out. This process is not discussed by Van den Berg, probably because it is irrelevant to the alternation at hand.

b. liedje (lied) 'song', ratje (rat) 'rat'

c. koppie (kop) 'cup', stoffie (stof) 'piece of textile', jassie (jas) 'coat', hakie (haak) 'hook', vliegie (vlieg), 'fly'

The forms are basically the same, and have the same distribution as they have in SD, except that in the latter variety the (1b) form is also used after non-coronal consonants (i.e. where the Randstad dialects have ie). We will therefore not discuss these rules here. Of particular interest are the forms in (1c), for which Van den Berg (1973) provides the following rule:

(2) je $\rightarrow$ ie / X

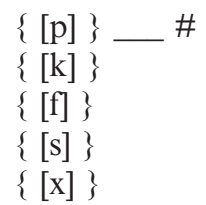

Van den Berg then goes on to discuss the nature of this rule, and concludes that it is a kind of 'reduction' rule in which two segments ([j] and [ü]) are reduced to one, e.g. by deleting the roundness feature of the [ü]). The reason for this reduction, according to Van den Berg, is the 'low sonority' of word-final unaccented [jü].

An important question here is why the context after voiceless coronal plosive [t] (i.e. (1b)) is excluded from (2). Van den Berg (1973) argues that / $\mathrm{t} / \mathrm{and} / \mathrm{j} /$ are merged into a single palatal plosive and that this in turn blocks the 'reduction' rule in (2).

De Wilde-Van Buul (1943) pointed out a similar reduction process, with a somewhat narrower geographical distribution, in the city dialect of Rotterdam. This concerns the second person (singular) clitic je. Van Oostendorp (2000) discusses her data and provides some additional forms (based on some limited fieldwork). In essence, the phonological distribution is the same as for the diminutive: we find je after coronal obstruents and ie almost everywhere else. Below, we have summarized Van Oostendorp's (2000) main findings. Notice that Van Oostendorp assumes that the vowel in the 'full' form is not [ü] but [ə], and he writes the palatal consonant as [c]:

(3) a. [i] - after any consonant except for coronal obstruents: hebbie 'have you', hoop ie
'hope you', pakkie 'take you' 
b. [jo]

- after non-high vowels: ga je 'go you', ree je 'drove you'

c. variation between [i] and [j]

- after high vowels: doe jeldoewie [dujə/duwi] 'do you', nu je/nuwie [nyjə/nywi] 'now you'

- after coronal fricatives, nasals and /1/: leesje/leessie [le $\mathrm{e} / \mathrm{lesi}$ ' $\mathrm{read}$ you', ben je /bennie 'are you', willie/wil je 'want you'

d. $[\mathrm{c}$ ]

- after (and merging with) coronal plosives

haat je [hacə] 'hate you', wed je [wecə] 'bet you'

Another important observation is that final devoicing is blocked in these cases. The second person singular form of 'to have' is hebbie, not *heppie. Hopie rather than *hobie shows that this is not a matter of intervocalic voicing. One could try to relate this to the fact that heppie has a different meaning, viz. 'he has' (presumably from heb tie). This contrasts with other clitic forms in which devoicing seems optional (Booij 1995): heb ik/ heppik [hebrk / heprk] 'have I'. Another observation is that the alternation is still specific to the diminutive suffix and the personal pronoun; it does not apply to lexical words (jenever 'Dutch gin', [jənevər]/*[inevər]; idee 'idea' *[jəde]/[ide]).

Van Oostendorp (2000) provides an analysis of these facts in terms of feature geometry and Optimality Theory, which is similar in spirit to Van den Berg's (1973) proposals. The underlying form is $/ \mathrm{j} /$, the optimal realization of which is [i], except where this would cause vowel hiatus (after non-high vowels) or where the $/ \mathrm{j} /$ merges with a [t]. The reason why there is variation (or optionality) after high vowels is that such vowels can solve the hiatus problem by glide insertion; the variation in the case of coronal fricatives may indicate that somehow the palatal fricative counts as more marked than the palatal stop, which does not alternate.

Van Oostendorp (2000) also notes that there seems to be regional variation: in certain areas close to Rotterdam, the accepted form for the diminutive is also tie, such as in dochtertie 'daughter'. On the other hand, the reduction of the second person singular clitic also seems to be regionally bounded: hebbie with the auxiliary 'have' has a wider regional distribution than other forms. However, these statements are not empirically substantiated in Van Oostendorp (2000), and I have not been able to find other sources which do, although I do not exclude the possibility that careful study of some of the larger databases might shed light on this issue.

The SAND and GTRP databases do not provide sufficient evidence on the distribution of the second person clitic. The forms in SAND have not been transcribed phonologically and are therefore difficult to search. The only relevant sentence in GTRP contains the sequence wil je (Wat wil je met dit brood doen? 'What do you want to do with this bread?'; see Map 21.1). This form shows a few entries for [i] in South Holland, but since there is already internal variation after a lateral in Rotterdam, and internal variation is not systematically noted, it is not so clear how to interpret this map.

The maps we can create for diminutive forms are more interesting. The following comparative map for boom 'tree' and kat 'cat', for instance, shows that the alternation between je and ie is indeed typical and distinctive for the dialects of Utrecht and Holland. Within this region, but not outside it, an -ie form appears in the former case and 


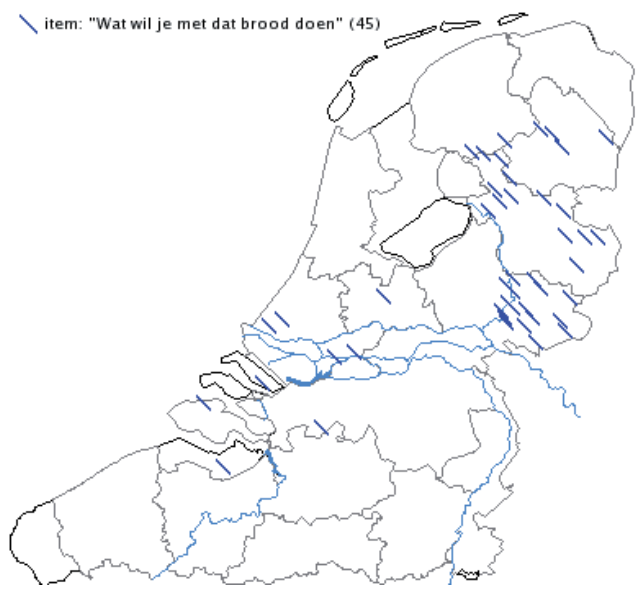

Map 21.1: Alternation between je and ie in wil je

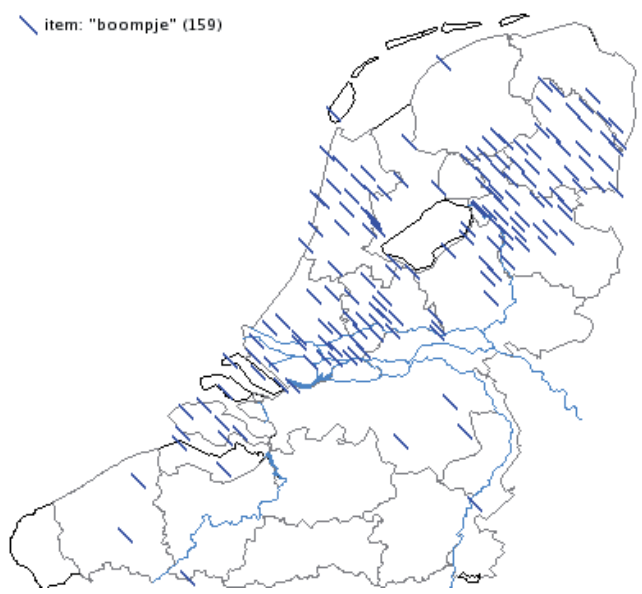

Map 21.2: Alternation between je and ie in boompje

a -je form in the latter, but elsewhere this alternation is not found (in the northeast of the Netherlands, there is a large area where there is a non-alternating form (with) $i e$ for the diminutive). On Maps 21.2 and 21.3 we find diminutives for boom 'tree' with [pi] and for kat 'cat' with [ti].

The GTRP data for dochter 'daughter' show a case where the vowel of the stem-final syllable is schwa, and a rather large region (from Zeeland across the south of Holland towards Utrecht) shows a [ti] form. Cases like this would be worth exploring in more detail (perhaps these varieties try to avoid two schwa syllables in a row).

There are some indications that the phenomenon is not entirely unconstrained, and that certain syntactic boundaries tend to be respected. Van Oostendorp (2001) gives the following examples: 


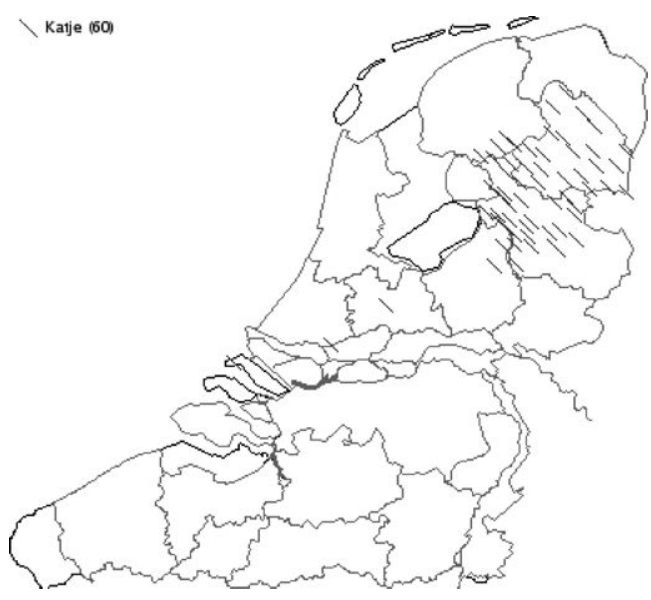

Map 21.3: Alternation between je and ie in katje

(4) a. Doet een sjaal om [i] nek.

do a scarf around-your neck

'Put a scarf around yur neck'

b. Om[i] oma komp, moete we stil zijn.

because-your grandmother comes, must we silent be

'We must be silent, because your grandmother will come.'

c. Azz[i] alles wat je heb [jo]*[i] oma moe geve, be je snel arm.

If-you everything what you have your grandmother must give, are you quickly poor

'If you have to give everything you have to your grandmother, you will soon be poor.'

(4a) and (4b) show how a second person possessive pronoun can encliticize to the preceding preposition or complementizer; (4c) shows that this is not possible between the head of a relative clause modifying a direct object and the possessive pronoun in the indirect object. One might suspect that the reason for this is that the (syntactic or prosodic) phrase boundary between the two words is too strong. However, this has never been systematically investigated.

\subsubsection{The realisation of tense mid vowels and diphthongs}

One rather salient property of Randstad dialects for speakers from other regions is the pronunciation of diphthongs and tense mid vowels. The latter are characterized by a slight offglide, making them more diphthongal, whereas the vowels which are diphthongs in other varieties as well as the standard variety are more open in their first part. 


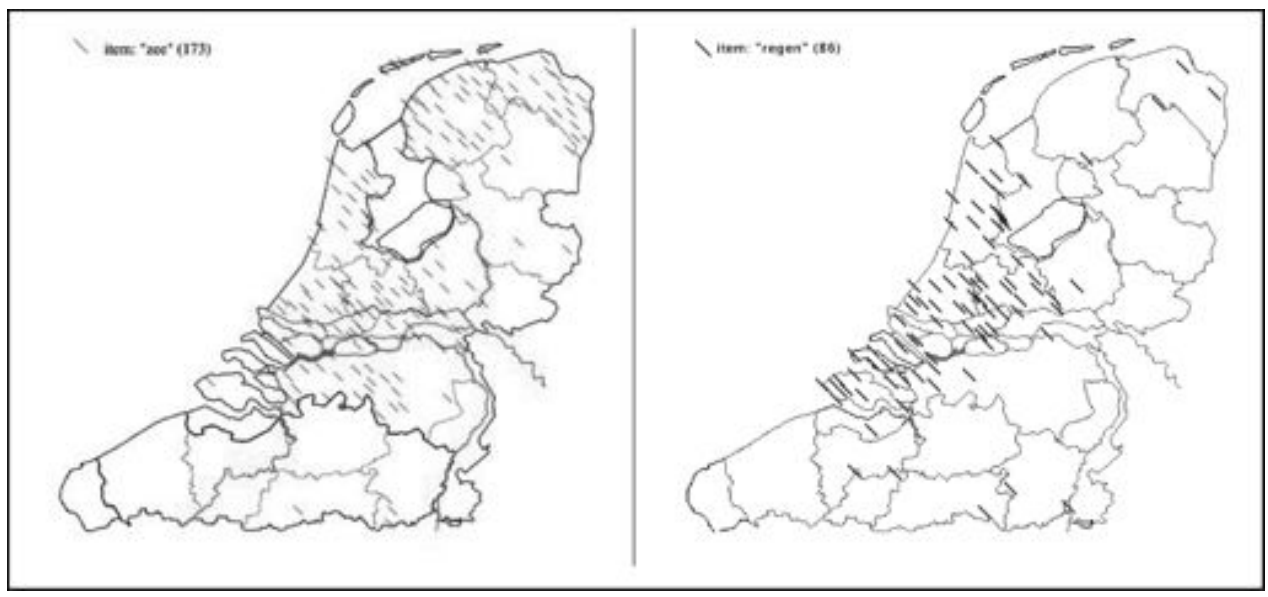

Map 21.4a: Diphthongal realizations of /e/ in Map 21.4b: diphthongal realizations of /e/ in re zee 'sea' gen 'rain'

These data are easily verifiable, both in the FAND and in the GTRP database. The following map shows the distribution of diphthongal realizations of /e/ in zee 'sea' and (the first syllable of) regen 'rain'. It is easy to see that in word-final position diphthongization is quite widespread (Swets 2004), whereas in word-internal position it is mostly restricted to Holland, Utrecht and Zeeland (FAND II/III shows a very similar pattern for words such as ezel 'donkey' and zeker 'sure').

FAND II/III notes (map 30) that the same region has diphthongization of tense long $o$ in geschoten 'shot'. FAND refers to Goeman (1984: 54-55) for support of the claim that this diphthongisation is due to influence of the standard language. Goeman gives an overview of the sound system of Zoetermeer in the course of roughly the first 80 years of the twentieth century, based on a variety of sources. These sources indeed show that around 1885 diphthongization was virtually absent in Zoetermeer. It therefore is a fairly recent characteristic of at least this town dialect, but it is not clear to me to what extent this should be ascribed to an influence of SD in the whole region. In the first place, standard norms for pronunciation are fairly weak and - in fact - diphthongization of the tense mid vowels arguably goes against the standard norms, and, secondly, they are based to a large extent on Randstad varieties.

If we accept that diphthongization in Holland dialects is due to standard influence, the question arises where the standard language in turn got the diphthongisation. It is also possible that the diphthongization is an urban development, having arisen first in Amsterdam, Rotterdam, The Hague and/or Utrecht, and spread from there to other Holland and Utrecht towns as well as to the standard language. In order to test this, we would definitely need more historical material from various parts of the region.

It is interesting to note that so far the change seems to be purely phonetic. According to all phonological tests available to us, $/ \mathrm{o}^{\mathrm{u}} /, \mathrm{e}^{\mathrm{i} /}$ and $/ \varnothing^{\mathrm{y}} / \mathrm{still}$ behave as monophthongs. For instance, they fill clear gaps in the phoneme system as mid counterparts to high /i, $\mathrm{y}, \mathrm{u} / \mathrm{and}$ low $/ \mathrm{a} /$ or as tense counterparts of $/ \mathrm{o}, \varepsilon, \mathrm{y} /$. Furthermore, the Dutch stress system is usually described as quantity-sensitive (Kager 1989, Booij 1995), with monoph- 
thongs counting as light and (true) diphthongs counting as heavy. The diphthongization of $/ \mathrm{o}^{\mathrm{u}} /, \mathrm{e}^{\mathrm{i} /}$ and $/ \varnothing^{\mathrm{y} /}$ so far has not led to any reorganisation of the stress system or of stress on individual words, as far as I am aware.

A third test works out in a slightly more complicated way. Trommelen and Zonneveld (1980) point out that diphthongs cannot occur before /r/ in SD. Diphthongisation of the tense mid vowels has a similar restriction, witness e.g. map 31 in FAND II/III on the verb boren 'to drill'. Here we find monophthongal realizations almost exclusively, showing that perhaps the constraint against diphthong $+/ \mathrm{r} /$ combinations has a phonetic basis, rather than a purely phonotactic one. (Another observation we can make is that in many varieties the mid vowels before $/ \mathrm{r} /$ are actually lax, rather than tense.)

Moving to the 'real' diphthongs (i.e. those sounds which are also diphthongs from the point of view of the phonological criteria just outlined), the picture is slightly less clear, mostly because strong diphthongization (i.e. extreme lowering of the first half of the diphthong) is also found outside of the Holland-Utrecht area. Furthermore, the traditional dialects of Amsterdam and The Hague had monophthongal realisations of

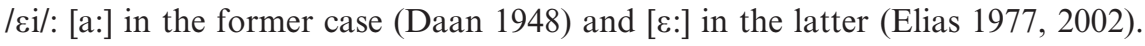

Diphthongs have been studied quite intensively for the so-called West Frisian dialects (a group of Holland dialects with Frisian roots); this is true in particular for the equivalent of the SD [ $\varepsilon i]$ sound, spelled $i j$ when it is etymologically a long high vowel, and $e i$ if it is not. In some West Frisian dialects (such as that spoken in the town Opperdoes), this etymological distinction is retained: $i j$ sounds as [aj] and ei as [oj]. Pannekeet (1991: 131) observes that in other dialects the split tends to be related to syllable structure: [aj] is the variant used in open syllables, whereas closed syllables have [oj] (see Jansen 2010 for a similar effect on Ameland). I have the impression that this picture is slightly idealized, and alternations like the following are not exceptionless in any dialect (furthermore [oj] can also be found in other Holland dialects, such as Volendam; see Van Ginneken 1954).

\section{(5) lijken 'to seem' [laj.kə] - (ik) lijk 'I seem' [lojk]}

The issue has gained some relevance since the publication of Stroop (1998), in which it is argued that a new variety of Dutch is arising, referred to as Polder Dutch. The main characteristic of this variety is diphthongization of mid vowels and a lowering of the onset of 'real' diphthongs. According to Stroop, the change is led by young, professional women, and did not have a clear regional basis; yet, Stroop does not provide a strong empirical basis for these claims. More recently, Jacobi (2009) provides a thorough investigation into the topic, mostly on the basis of material from the Corpus Gesproken Nederlands (CGN, Corpus Spoken Dutch - see < http://www.tst.inl.nl/cgndocs/>), and concludes that indeed a change seems to be going on, which is not clearly associated with a specific region or a gender, but which does seem to be led by higher socio-economic classes. However, as Jacobi indicates, given the design of the CGN the conclusions about the regional basis should be taken with some care. In any case, our previous discussion clearly shows that both vowel-related phenomena were present in the rural dialects of Holland and Utrecht before the rise of Polder Dutch. It is possible, of course, that the latter is an independent, later development - Stroop suggests that lowering of the initial part is a natural movement for vowels to make and that does not seem an 
absurd claim - but given the economic and social strength of these dialects, the idea that here we may be dealing with a modern instance of "Holland expansion" (Kloeke 1927) cannot be excluded either.

\subsubsection{Schwa as a reduced full vowel}

Many dialect descriptions of individual dialects note that the Holland (and Utrecht) dialects show much more vowel reduction than the standard language. For instance, Van Ginneken (1954) gives the following examples for Volendam:

\section{(6) $r[$ [ə]m[ə]tiek 'rheumatism', $a b$ [ə]dant 'abundant', g[ə]rdijn 'curtain'}

It should be noted that in the modern phonological literature on Dutch (Kager 1989, Booij 1995, Ernestus 2000) very similar data are often discussed as if they are part of the (informal) standard language.

It could be interesting to carry out a precise phonetic survey of ways in which /ə/ is realized phonetically in different regions. There are some informal observations in the literature; for instance that schwa is realized as rather front in The Hague, except that the combination with a final /r/ merges into [в] ( $\operatorname{vad}[$ б] 'father'). Overdiep (1940: 90) has a particularly poetic description of schwa in Katwijk (a town at the North Sea coast) and the Holland dialects in general (my translation):

Even if the stressless syllable at the end of an affective or emphatic sentence is accentuated, as in the 'sung' or 'chanted' language of the fishermen at sea during their activities, when they are calling another ship or commanding each other, /// sounds like the ordinary $u$ of hut [i.e. [Y]]. Yet /o/ is the 'tonal' basis of phrasal rhythm and intonational form in every Holland dialect. It's the ever sounding 'voice' in the Hollander's way of talking: supple and rattling, yet also monotonous, musical but also nagging.

At present there are more precise instrumental means to test claims such as this one: the sound files of the GTRP database could form a starting point, but unfortunately, this kind of acoustic work has not yet been done.

\subsection{Consonants}

\subsubsection{Velar fricatives}

Another phonetic property which the Holland and Utrecht dialects have in common is a very back, almost uvular pronunciation of the velar fricative. The literature does not contain a lot of concrete data on this phonetic difference, for instance because the relevant databases do not show enough phonetic detail to explore the issue directly. Indirectly, however, some evidence can be found. In particular, uvular fricatives are very difficult to produce with voicing (Van de Velde 1996). Interestingly, it is sometimes observed that $/ \mathrm{r} /$ is pronounced as a voiced uvular fricative [ $\mathrm{G}$ ]; Fehringer 1999 claims that this is the case for the Amsterdam dialect. 
There are many dialects, especially in the Netherlands, in which the contrast between voiced and voiceless fricatives is phonetically blurred, in particular in word-initial position. What is quite specific for Holland dialects, however, is that voiced fricatives no longer occur even in typical voicing contexts, i.e. intervocalically or between a sonorant and a vowel. FAND maps 123 (dragen 'to carry'), 139 (volgen 'to follow') and 140 (morgen 'tomorrow') illustrate this point: we only find voiceless realizations of the fricatives in these positions.

It should be noted that the voiceless realization of all fricatives is almost a shibboleth for Northern Holland dialects, and in particular for Amsterdam. Yet FAND shows that other fricatives do not display similar behaviour: /v/ and /z/ tend to be voiced in similar positions, even in dialects which elsewhere no longer have a voicing contrast (this may therefore be a case of intervocalic voicing). Furthermore, hypercorrections are sometimes reported for /f/ and especially /s/ (saying [z]uiker for suiker 'sugar'), but not for the velar fricatives.

It is also worth noting that in this case, too, the phonetic merger of voiced and voiceless (velar) fricatives has not yet been completely phonologized. One process which is sensitive to the voicing specification of (stem-final) fricatives is allomorph selection: -te appears after voiceless obstruents, and -de elsewhere. The verb vlaggen 'to flag', with an underlying voiced fricative, still selects the -de allomorph (vlagde), while lachen, with an underlyingly voiceless segment chooses -te (lachte), even if both fricatives are realized in exactly the same way.

A completely different aspect of velar fricatives is that they are not always found after $s$; for instance West Frisian (Pannekeet 1991), Katwijk (De Vink 2004) and Volendam (Van Ginneken 1945) have maintained the (original) [sk] cluster in words like skool 'school', and not shifted to [sx]. See FAND IV map 123.

\subsubsection{T-insertion and n-insertion}

Variable deletion of / $/$ / is all but specific for Holland and Utrecht dialects, as Goeman (1999) has demonstrated. As a matter of fact, in FAND IV we find much more deletion of suffixal /t/ (denoting third person singulars of verbs, as in hij hang(t) 'he hangs') for instance, in the east of the Netherlands than in the region which is under discussion here.

For some regions - in particular the city dialect of Utrecht - it has been noted (Scholtmeijer 1997, Van Oostendorp 2001) that the deletion of /t/ (7a) is mirrored by a process of $/ \mathrm{t} /$ insertion (or paragoge, $(7 \mathrm{~b})$ ):

(7) a. Optional /t/ deletion: $d a(t)$ 'that', Uterech( $t$ ) (toponym), soor ( $t$ ) 'type'

b. Optional /t/ insertion (after sonorants): dubbel $(t)$ 'double', enkel $(t)$ 'only', brom$\operatorname{mer}(t)$ 'motorized bike'

Since both processes are optional, one could say that the choice which of the two is considered "real" in the dialect (i.e. if we assume underlying /t/ with deletion or underlying zero with insertion) is arbitrary from a synchronic, dialect-internal point of view. In the example in (7) the underlying status has been motivated by comparison with other dialects and etymology: I categorized the examples in (7a) as deletion because the /t/ 
appears in other varieties, and those in (7b) as insertion, because in these /t/ does not. The insertion cases seem to be found only after sonorants.

Scholtmeijer (2002) reports that after word-final $/ \mathrm{m} /[\mathrm{p}]$ rather than [t] may appear, as in $\operatorname{glom}(p)$ 'glimmered' (etymologically this is a strong past tense form glom with a paragogic segment - a phenomenon which he plausibly explains as place assimilation.

My impression is that similar phenomena can be found elsewhere in the region. For instance, Heestermans (2008) reports /t/ deletion and insertion in Leiden, with an extra twist: /t/ is also deleted before /s/ (8a); furthermore, according to Heestermans, /t/ insertion is found only in contexts after /s/ (8b):

(8) a. $\operatorname{praa}(t) s$ 'chat', $k o e(t) s$ 'charriot'

b. $\operatorname{gas}(t)$ 'gas', $k a n s(t)$ 'chance'

Heestermans claims that fricatives can also optionally be deleted before /s/: sunda $(\chi) s$ 'on Sunday', stij(f) sel 'starch'.

Interestingly, in (older varieties of) Utrecht we can also find traces of something similar involving $/ \mathrm{n} /$ : this consonant is optionally deleted after schwa, but also optionally inserted after that vowel when it occur in hiatus position. The former process happens in a very large area of the Dutch-speaking world, while the latter is more typical of eastern varieties of Dutch (and German).

(9) a. Optional /n/ deletion: bova(n) 'up', deka(n)s 'blankets', bə(n)zine 'petrol'

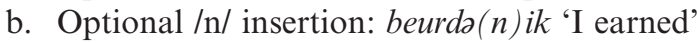

Scholtmeijer (1997) suggests that the existence of this phenomenon classifies Utrecht partly as a rather 'eastern' dialect, but Overdiep (1940) gives examples from Katwijk (at the North Sea coast, i.e. the westernmost border of the Netherlands), and Van Bree (2004) gives similar examples for South Holland, but without references. He observes that in auxiliaries $/ \mathrm{n} /$ can also be deleted after full vowels: ben je 'are you' [beja], which again is something that might have a larger geographic distribution.

With respect to the Katwijk dialect, Overdiep (1940) makes one further observation that is also interesting. He claims that insertion of /t/ (or /d/ word-internally) can have an 'affective or emphatic' effect. As an example, he gives the superlative of innelek [Inələk] 'close to the coast' (presumably from inner 'inner' + adjectivizing -lijk), which is indelekst.

\subsubsection{Voicing assimilation}

A process in the city dialect of Utrecht which has received some attention even in the international phonological literature (Bakovic 2007) is voicing assimilation. This phenomenon (Scholtmeijer 1997, 2002, Van Oostendorp 2001) is spectacular for two reasons. First, it seems that both voicing and voicelessness spread (regressively, from the stem to a proclitic); secondly, voicing can spread across schwa:

(10) a. /də pstorr/ 'the priest' [to pstorr]

b. /də bakər/ 'the baker' [də bakər] 
c. /tə pro:tə/ 'to talk', [tə pro:tə]
d. /tə bakən/ 'to bake'

Not many cases are reported in the literature where voicing assimilation can cross a vowel; Bakovic (2007) analyses the New Julfa dialect of Armenian (Vaux 1998) in this way, but I am not aware of other cases (indeed, Bakovic uses the Utrecht evidence to argue that this Armenian dialect is not alone in having this type of process).

\subsection{4. $n+$ coronal obstruent}

A well-known historical phonological process in (mostly) Holland is velarization of $/ \mathrm{n} /$ after a back vowel and before a coronal obstruent (Van den Berg 1943, Boekenoogen 1897, Daan 1985, 1995, 1997, Hoeksema 1999). An example is [hont] for hond 'dog' or [hant] for hand (id.). One peculiar thing to note here is that this process seems to have been very widespread in rural Holland in the seventeenth century, when it was used as a kind of sociolinguistic marker by playwrights who wanted to characterize peasants, but it has all but disappeared since then. Daan (1950) still observed the phenomenon in Wieringen Dutch and Mittelmeijer (1959) claims to have heard it from a 14-year old in Amsterdam. Overdiep (1940) found a few lexicalized relics in Katwijk, and De Vos (2009) reports it for the dialect of Charlois (close to Rotterdam). Van Oostendorp (2000) gives an analysis of data from most of these sources in terms of Optimality Theory and autosegmental phonology.

The phenomenon had a counterpart: palatalization of /n/ after front vowels, also in the seventeenth century, at least in Waterland, or to be even more precise: at least in the rendering of the Waterland dialect by the comic playwright Bredero. Van Ginneken (1935: 312) summarizes the situation as follows (my translation; I also replaced Van Ginneken's orthography by IPA at the relevant points; it should be kept in mind that this is my interpretation):

Next to [ayd]er (ander 'other'), br[ank]t (brandt 'burns'), $d[\mathrm{a \eta j}]$ sen (dansen 'to dance'), ged[a] $]$ st (gedansd 'danced'), [...] h[on]derd (honderd 'a hundred'), $h[\circ \mathrm{on}] k t$ (hond 'dog'), $m[$ onk $]$ (mond 'mouth'), [...] all after velar vowels, as we can see, after palatal vowels we find $k[$ in] $t(s)$ (kind 'child'), D [in]sdaechs (dinsdags 'on Tuesday'), l[in]de (linde 'linden'), ontb[in]den (ontbinden 'decompose'), $k$ [ij]eren (kinderen 'children') from $k$ [Ein]eren and $I[\mathrm{in}]$ en (Indiën, India).

I have no indication that the palatalization can still be found anywhere in the area. On the other hand, some processes still take place in /Vnd/ and /Vnt/ clusters. Van Ginneken (1954) notes that in Volendam certain vowels (/a/ in Volendam, /I/ in Monnikendam) have diphthongized before clusters of this type:

(11) Volendam: $l$ [aj] $n t$ 'land', $t$ [aj]nt 'tooth', $d$ [aj]nse 'dance'

Monnikendam: $w$ [aj] nt 'wind', $b$ [aj]nde 'bind', $w$ [aj]nter 'winter'

Yet another effect, noted by J. Berns in Spaans (2004) for the coastal dialect of Scheveningen, is deletion of ' $\mathrm{d}$ ' in forms such as vinnen (> vinden) 'to find'. 
The cluster seems to have an effect mostly on the vowel in the present age. Schatz (1987) observes that short vowels before such clusters are lengthened and nasalized, while the nasal consonant itself may disappear or be just barely pronounced; a similar observation is made by Pannekeet (1991) for West Frisian. See also Hinskens and Van Oostendorp $(2004,2006)$ for an overview, also outside of the Dutch-speaking area proper.

\subsection{5. $R$}

Like in other regions, there is a lot of variation in the production of the $/ \mathrm{r} /$ sound, ranging over $[\mathrm{r}, \mathrm{I}, \mathrm{R}, \mathrm{I}, \mathrm{\textrm {B }}, \mathrm{j}]$ and many others. In my view, it is very difficult to say anything about this variation given our current state of knowledge: the sources are very impressionistic, not necessarily consistent with each other and one is left with the impression that the phonetic realization is in a state of constant flux. It would be necessary to make precise acoustic and articulatory measurements, but these are simply lacking. An interesting feature of most dialects is that more vocalized or weakened allophones of the rhotic can only be found in coda position:

(12) raar 'strange' [rагь, ra:r, *ьагь, * ка:r]

The exception is the city dialect of Leiden, which has a rhotic that could be described as retroflex in all positions ([-[a:-t]; Wortel 2002).

\subsection{6. $\mathrm{H}$}

Older dialect descriptions report the absence of $h$ in many cases. Lafeber (1967), for instance, states that the present generation in Gouda pronounces this sound, but earlier generations did not. FAND maps 214 and 215 show that the phenomenon can nowadays only be found at most in a few coastal dialects (Gouda is a town right in the heart of Holland, so not close to the coast).

Lafeber (1967) makes a very intriguing observation (hitherto neglected in the literature) concerning the $h$-less variety of Gouda. He shows that there are quite a few phonological differences between a word like hout 'wood' [aut] with an etymological $h$ and a word like oud 'old' [aut] without such an etymology. According to several criteria it looks as if hout type words started with a consonant (similar to what we know of $h$ aspiré in French; I will therefore refer to words of this type as $h$ aspiré here as well). Here are a few of Lafeber's observations.

First, word-final plosives are (often) voiced when the following word starts with a vowel:

(13) a. Laa je an[t] sakke 'Let your hand go down' vs.

b. Au je an[d] op 'Raise your hand' 
c. Eij gee[f] meij boeke 'He gives me books' vs.

d. Eij gee[v] en boek 'He gives a book'

However, this is not the case if the following word starts with an $h$ aspiré:

(14) a. da[t] êêle zaakie 'that whole affair'

(cf. hele 'entire')

b. Eij gee[f] em en boek 'He gives him a book'

(cf. hem 'him')

Interestingly, the final [t] of the negation marker niet is insensitive to the presence of $h$ aspiré and voices anyway:

(15) a. nie[d] oud 'not old'

b. nie[d] ange 'don't hang' (cf. hangen 'hang')

Another indication for the $h$ aspire status is that schwas are not deleted before words with an haspiré:
(16) a. nââ d' overkant
'to the other side'
b. nââ d[ə] ôôge kant 'to the high side'
(cf. hoge 'high')

It therefore looks as if, at least in Gouda, there was still some kind of phonological marker of the historical presence of $[\mathrm{h}]$ in the first half of the twentieth century (when Lafeber conducted his study). A clearly pronounced [h] has now filled that position.

The sandhi status of intervocalic voicing, which above was used in order to establish the presence or absence of (initial) /h/, has also been noted elsewhere in the Holland area. Overdiep (1940) mentions this process for Katwijk. In (17a), the [d] is a reflex of the inflectional ending which would normally be transcribed as /t/. However, here too an $h$ aspiré can block the voicing (17b) and cf. (14) above:

(17) a. 't Huisje stae[d] an de Noortkant.

The house is located on the northern side

b. Dauw[t] em weg!

Push him away!

\subsection{Prosodic phenomena}

Generally speaking, Dutch dialects do not show many systematic differences in syllable structure or higher-order prosody (the Limburgian dialects show tonal alternations, but even these can be seen as mere segmental interpretations of general prosodic differences; see Hermans, Ch. 18 in this volume).

One important distinguishing feature may consist of intonation. In dialect descriptions there are sometimes references to the 'singsong' intonation that many Holland and Utrecht dialects are supposed to have. It is very unfortunate that presently no published research is available that sheds light on this matter.

I know of one description of a Holland dialect in which a metrical aspect is discussed which is a little different from what we know in the standard language, and presumably 
other Dutch dialects. This concerns compound stress in West Frisian. Compound stress in general seems to be a matter of dialectal variation, but Pannekeet (1991) notes that there seems to be some regularity in the exceptionality of stress in West Frisian. According to Pannekeet, "rather many compounds in West Frisian have word accent on a different syllable than in corresponding or similar Dutch words. Characteristic of West Frisian is that in many cases (...) word stress is on the (pre)final syllable." Similar stress patterns can be found in Frisian. In particular, this would be the case for compounds "of which the first component is a concrete noun describing objects in and around the house" (p. 232):

(18) keuken-d'eur 'kitchen door' kelder-tr'ap 'cellar stairs' kamer-l'amp 'room lamp'

Another category consists of 'dialect compounds' (presumably, compounds which have no direct equivalent in the standard language; it strikes me that the examples which Pannekeet mentions could also either fit into the previous category or describe human beings):

(19) $\begin{aligned} & \text { keuke-kl'eidje } \\ & \text { vraaigezellem 'oid }\end{aligned} \quad$ 'bitchen cloth'
'bachelor girl' (probably: spinster)

\section{Desiderata}

Very little is known about the sound structure of Holland dialects. Part of the reason for this is that these dialects have not been taken as seriously as the dialects of other regions by dialectologists, which in turn may have been caused by the fact that they are less 'exotic' to the student of SD - if only for their relative structural closeness to the standard language. They usually also do not attract the attention of amateurs to the same extent as other dialects, possibly because there is less dialect awareness in these regions. Much is therefore left to be desired for anyone who is interested in these regions, but given the fact that this interest is not widespread it is not clear that such desires will soon be satisfied. In this section, I will provide a few suggestions about the most obvious gaps, and ways in which these can be filled.

It should be observed, first, that phonetic studies for this region are all but absent. Researchers interested in phonetic regional variation do sometimes record Randstad speakers as subjects, but only as a benchmark for 'standard' language. This means that next to nothing is known about the actual regional variation. Two important databases which may be of help in this respect are the GTRP database and the Soundbites database, both at the Meertens Institute (see Barbiers and Goeman, Ch. 34 in this volume for discussion). Two of the questions which might be adressed are:

- What is the precise realization of individual segments which are known to vary, such as $/ \mathrm{r} /$, schwa, the velar fricatives and the tense vowels?

- What are the characteristic intonational patterns of these dialects? For instance, the patterns of Rotterdam and those of Amsterdam are impressionistically very different, 
but there is literally no literature at all on this. (This also applies to all other regions in the Dutch language area, with Limburg as the only exception.)

Secondly, there is very little information on the rural areas which are not either (a) on the coast or (b) in West-Frisia, e.g. the towns of Alkmaar in North Holland or Alphen aan den Rijn in South Holland. These are simply white spots on our linguistic maps. Some fieldwork has been done here and there for larger fieldwork projects such as RND and GTRP, but there are no sources that go into any detail, like a monograph or a grammatical sketch.

Thirdly, even for the areas (a) and (b) mentioned above, and even in the current situation, a wide range of phenomena probably still remain to be studied. Above various phenomena were discussed that are quite curious from a typological perspective, such as the voicing assimilation across schwas in Utrecht, the sandhi voicing blocked by $h$ aspiré, the multitude of phenomena involving nasal plus obstruent clusters, and the diphthongization of mid vowels. Holland and Utrecht together host five vibrant linguistic departments (at Leiden University, Utrecht University, the VU University Amsterdam, the University of Amsterdam and the Meertens Institute), so there may be at least some linguists there with some interest in the local language varieties. All of these topics deserve further scrutiny. There is still a lot of work to be done.

\section{Atlases}

FAND $\cdot$ MAND $\cdot$ SAND

\section{References}

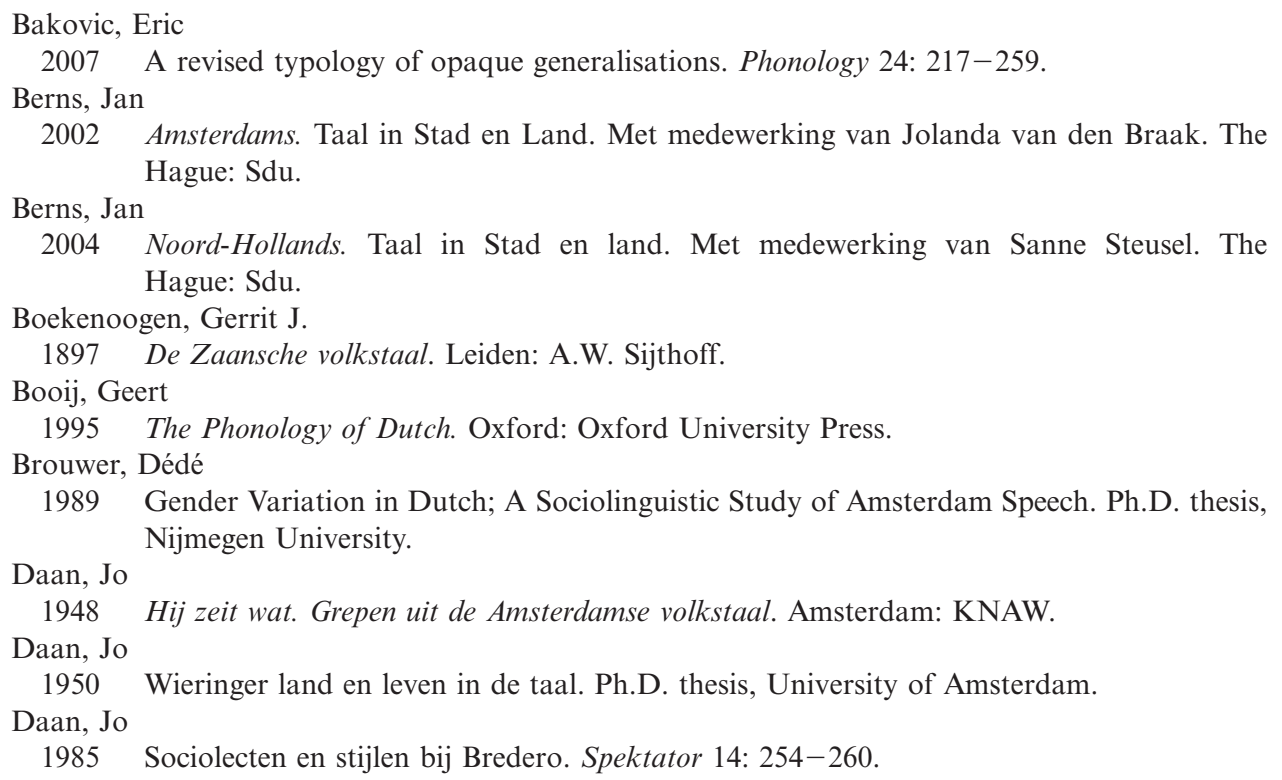


Daan, Jo

1995 Sociolecten in de achttiende eeuw. In: José Cajot, Ludger Kremer and Hermann Niebaum (eds.), Lingua Theodisca. Beiträge zur Sprach- und Literaturwissenschaft. Jan Goossens zum 65. Geburtstag, 263-269. Münster/Hamburg: Lit.

Daan, Jo

1997 Stads- en buitenlui. Typering door velarisering. In: Ariane van Santen and Marijke van der Wal (eds.), Taal in tijd en ruimte. Voor Cor van Bree bij zijn afscheid als hoogleraar Historische Taalkunde en Taalvariatie aan de Vakgroep Nederlands van de Rijksuniversiteit Leiden, 183-191. Leiden: SNL.

De Vink, Leendert

2004 Dialect en dialectverandering in Katwijk aan Zee. Ph.D. thesis, Leiden University.

De Vos, Stephan

2009 Sjaarloos woordenboek. Rotterdam: Stichting Historisch Charlois.

De Wilde-van Buul, G.

1953 Het enclitisch pronomen van de 2e en 3e persoon singularis in het Rotterdams. Tijdschrift voor Nederlandsche taal-en letterkunde 62: 290-301.

Elias, Michael

1977 Plat-Haags: een verkennend onderzoek naar enkele aspekten van het taalgebruik en de taalattitude van mannelijke Hagenaars in en om de Schilderswijk. Amsterdam: University of Amsterdam.

Elias, Michael

2002 Haags. In samenwerking met Ton Goeman. The Hague: Sdu.

Fehringer, Carol

1999 A reference grammar of Dutch. Cambridge: Cambridge University Press.

Goeman, Ton

1984 Klank- en vormverschijnselen van het dialect van Zoetermeer. Amsterdam: P. J. Meertens-Instituut.

Heestermans, Hans

2007 Het Leids woordenboek. Leiden: selexyz Kooyker.

Hinskens, Frans and Marc van Oostendorp

2004 Coronale nasaal-plosief clusters in de Nederlandse dialecten. Een verkenning. In: Johan de Caluwe, Magda Devos and Jacques Van Keymeulen (eds.), Schatbewaarder van de taal. Liber amicorum Johan Taeldeman, 519-545. Ghent: Academia Press.

Hinskens, Frans and Marc van Oostendorp

2006 De palatalisering en velarisering van coronale nasaal-plosief clusters in GTR. Talige, dialectgeografische en onderzoekerseffecten. Taal en tongval 58(1): 103-122.

Hoeksema, Jack

1999 Velarisatie van /n/ in plat Hollands. TABU XX: 94-96.

Jacobi, Irene

2009 On variation and change in diphthongs and long vowels of spoken Dutch. Ph.D. thesis, University of Amsterdam.

Jansen, Mathilde

2010 Language Change on the Dutch Frisian Island of Ameland. Linguistic and sociolinguistic findings. Ph.D. thesis, VU University Amsterdam.

Kager, René

1989 A Metrical Theory of Stress and Destressing in English and Dutch. (Linguistic Models 14.) Dordrecht: Foris Publications.

Kloeke, Gesinus G.

1927 De Hollandsche expansie in de zestiende en zeventiende eeuw en haar weerspiegeling in de hedendaagsche Nederlandsche dialecten: Proeve eener historisch-dialectgeographische synthese. The Hague: Noord- en Zuidnederlandsche Dialectbibliotheek. 
Lafeber, Abraham P. M.

1967 Het dialect van Gouda. Gouda: Oudheidkundige kring 'Die Goude'.

Martens van Vliet, Bernhard J.

2000 De vollekstaol van de stad Uterech. Woorden, gezegdes, uitdrukkingen en zinsneden. Met medewerking van Harrie Scholtmeijer. Utrecht: Stichting Publikaties Oud-Utrecht.

Mittelmeijer, Joop

1959 Taalkundige observatie van de schoolgaande jeugd in de Jordaan. B.A. thesis, Nijmegen.

Overdiep, Gerrit S.

1940 De volkstaal van Katwijk aan Zee. Antwerp: De Sikkel.

Pannekeet, Jan

1991 Het Westfries. Inventarisatie van dialectkenmerken. Wormerveer: Stichting Uitgeverij Noord-Holland.

Schatz, Henriëtte

1986 Plat Amsterdams in its social context. A sociolinguistic study of the dialect of Amsterdam. Amsterdam: P. J. Meertens-Instituut.

Schatz, Henriëtte

1987 Lik op stuk. Het dialect van Amsterdam. The Hague: BZZTôh.

Scholtmeijer, Harrie

1997 Aspecten van de klank- en vormleer van het Stad-Utrechts. In: Bernhard J. Martens van Vliet (ed.), De vollekstaol van de stad Uterech, 15-37. Utrecht: Stichting Publikaties Oud-Utrecht.

Scholtmeijer, Harrie

2002 Utrechts, Veluws en Flevolands. Taal in Stad en Land. The Hague: Sdu.

Spaans, Piet

2004 De spreektaal van de Scheveningse kustbewoners. The Hague: De nieuwe Haagsche.

Stroop, Jan

1998 Poldernederlands, waardoor het ABN verdwijnt. Amsterdam: Bert Bakker.

Van Bree, Cor

2004 Zuid-Hollands. Hollands tussen Haringvliet en IJ. Taal in Stad en land. The Hague: Sdu-Uitgevers.

Van den Berg, Berend

1943 Boers en beschaafd in het begin der 17e eeuw. De Nieuwe Taalgids 37: 242-246.

Van den Berg, Berend

1959 Het dialect van Zandvoort en zijn plaats in de Hollandse dialecten. Amsterdam: NoordHollandsche Uitgeversmaatschappij.

Van Ginneken, Jacques

1935 De correlatie van harde en weeke medeklinkers in het Oud- en Nieuwnederlandsch. Onze Taaltuin 3(10): 302-317.

Van Ginneken, Jacques

1954 Drie Waterlandsche dialecten. Deel I. Grammatica, phonologie, klankleer. Bezorgd door A. Weijnen. Alphen aan den Rijn: Samsom.

Van Oostendorp, Marc

2000a Phonological Projection. Berlin: Mouton de Gruyter.

Van Oostendorp, Marc

2000b. Wieringse nasaalvelarisering. Taal en Tongval 52(1): 163-188.

Van Oostendorp, Marc

2000 Coronalen in het stad-Utrechts en de structuur van het fonologisch woord. Taal en Tongval, thematic issue 17: 123-145.

Van Oostendorp, Marc

2002 Rotterdams. Taal in Stad en Land. The Hague: Sdu. 


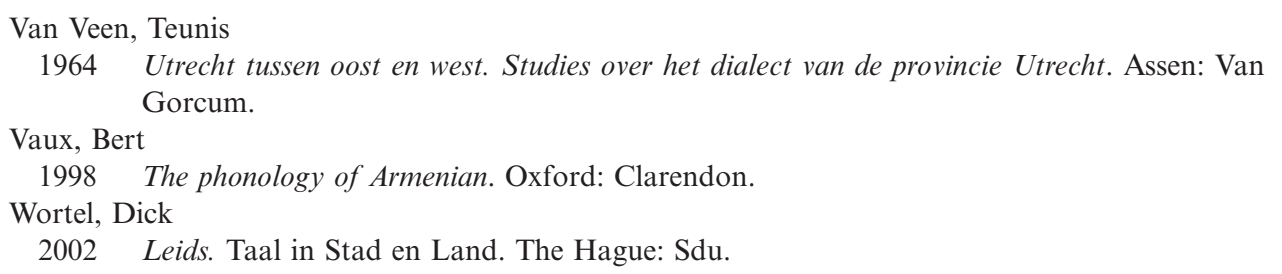

Marc van Oostendorp, Amsterdam (The Netherlands)

\section{Holland and Utrecht: Morphology and syntax}

1. Introduction

2. Derivational morphology

3. Inflectional morphology

4. Syntactic categories

5. Negation

6. Suggestions for further research

7. Atlases

8. References

\section{Introduction}

This article discusses the varieties of Dutch spoken in the provinces of South Holland, North Holland and Utrecht. The dialect of North Holland, and in particular the dialect spoken in the Westfriesland area (West Frisian), is best described in the literature as far as syntax and morphology are concerned. In English, West Frisian is normally used to refer to the Frisian language spoken in the province of Friesland; we refer to this language as 'Frisian', as is common in Dutch.

This paper makes extensive use of dialect studies on particular dialects in the three provinces under discussion (for instance, Pannekeet 1979, 1995 and Overdiep 1940) as well as the morphological and syntactic dialect atlases that have appeared in recent years. We refer to the two morphological atlases as MAND I and MAND II, see De Schutter et al. (2005) and Goeman et al. (2008), respectively, and to the two syntactic atlases as SAND I and SAND II (Barbiers et al. 2005 and Barbiers et al. 2008, respectively). We will also make use of data gathered in the so-called DiDDD-project (Diversity in the Dutch DP Design, see Corver et al. 2007). This latter project is restricted to variation in the nominal domain in the Dutch dialects.

This article necessarily takes a bird-eye's view of the morphological and syntactic variation, but potentially interesting phenomena receive special attention. For lexical and dialect-geographical information, see also Hoekstra and Scholtmeijer (2004). 